\section{MRI after thoracic epidural blood patch}

Ralf Giess, MD, Peter Landwehr, MD, and

Fedor Heidenreich, MD, Hanover, Germany

A 60-year-old woman presented with a history of trigeminal neuralgia. Results of cranial MRI were normal, but T2-weighted MRI of the cervicothoracic spine revealed an epidural hyperintense signal extending from vertebra $\mathrm{C} 7$ to the caudal thoracic spine (figure). After imaging, the patient reported that she had successfully received an epidural blood patch because of postural headache and low CSF pressure 22 months earlier. Assuming spontaneous intracranial hypotension, $30 \mathrm{~mL}$ of autologous blood had been injected at level T8.

Epidural blood patch is an effective treatment for spontaneous CSF leaks. ${ }^{1}$ Blood spread over five to ten spinal segments after injection of 18 to $20 \mathrm{~mL}$ blood has been demonstrated by MRI, but long-term observation is not available. The extent of spread appears to be related to the injection volume and spread of the blood clot is usually in the cephalad direction. Blood patch should therefore be performed below the suspected CSF leak. ${ }^{2}$ Typically, blood accumulates mainly in the posterior epidural space after blood patch, but anterior layering of blood has been reported in one of five patients. $^{2}$ In these patients, chronic subdural hematoma or hygroma with high protein concentration must be considered, but can be differentiated with MRI.

1. Sencakova D, Mokri B, McClelland RL. The efficacy of epidural blood patch in spontaneous CSF leaks. Neurology 2001;57:1921-1923.

2. Vakharia SB, Thomas PS, Rosenbaum AE, Wasenko JJ, Fellows DG. Magnetic resonance imaging of cerebrospinal fluid leak and tamponade effect of blood patch in postdural puncture headache. Anesth Analg 1997; $84: 585-590$.
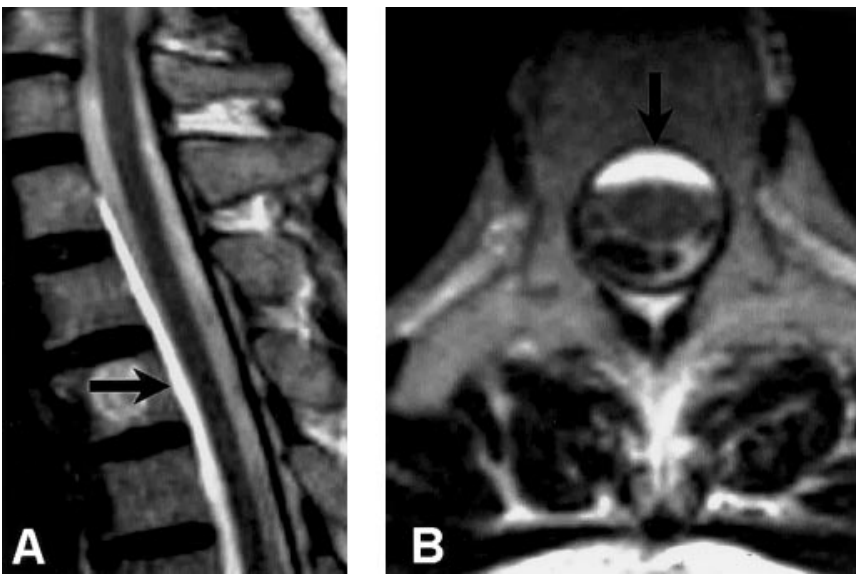

Figure. T2-turbo spin-echo MRI of the cervicothoracic spine. Sagittal (A) and transversal (B) sections show a hyperintense epidural fluid collection (arrows) indicating high protein containing remnants of the epidural blood clot extending from vertebra $C 7$ to the thoracic spine. $\overline{\text { See also page } 1450}$

Address correspondence and reprint requests to Dr. Ralf Giess, Department of Neurology, Henriettenstiftung, Hannover Medical School, Schwemannstrasse 19, D-30559 Hannover, Germany; e-mail: ralf.giess@ henriettenstiftung.de 


\section{Neurology}

MRI after thoracic epidural blood patch

Ralf Giess, Peter Landwehr and Fedor Heidenreich

Neurology 2003;61;1449

DOI 10.1212/01.WNL.0000082655.33469.F2

This information is current as of November 24, 2003

\section{Updated Information \&} Services

References

Permissions \& Licensing

Reprints including high resolution figures, can be found at: http://n.neurology.org/content/61/10/1449.full

This article cites 2 articles, 1 of which you can access for free at: http://n.neurology.org/content/61/10/1449.full\#ref-list-1

Information about reproducing this article in parts (figures,tables) or in its entirety can be found online at:

http://www.neurology.org/about/about_the_journal\#permissions

Information about ordering reprints can be found online: http://n.neurology.org/subscribers/advertise

Neurology ${ }^{\circledR}$ is the official journal of the American Academy of Neurology. Published continuously since 1951, it is now a weekly with 48 issues per year. Copyright . All rights reserved. Print ISSN: 0028-3878. Online ISSN: 1526-632X.

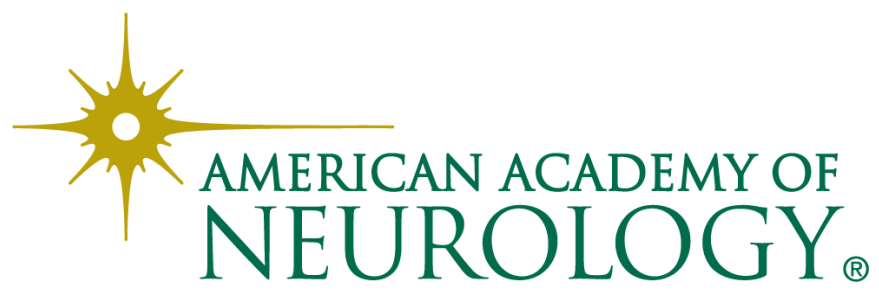

